\title{
SUBSTRATE, LIME, PHOSPHORUS AND TOPDRESS FERTILIZATION IN MACAW PALM SEEDLING PRODUCTION ${ }^{1}$
}

Leonardo Duarte Pimentel ${ }^{2 *}$, Claudio Horst Bruckner ${ }^{3}$, Candida Elisa Manfio $^{4}$, Sérgio Yoshimitsu Motoike and Hermínia Emília Prieto Martinez ${ }^{6}$

\footnotetext{
${ }^{1}$ Received on 06.03.2014 accepted for publication on 16.12.2015.

${ }^{2}$ Universidade Federal de Viçosa, Departamento de Fitotecnia, Viçosa, MG - Brasil. E-mail: <leonardo.pimentel@ufv.br>.

${ }^{3}$ Universidade Federal de Viçosa, Centro de Ciências Agrárias, Departamento de Fitotecnia, Viçosa, MG - Brasil. E-mail: $<$ bruckner@ufv.br>.

${ }^{4}$ Universidade de CruzAlta, Mestrado Profissional em Desenvolvimento Rural, CruzAlta, RS - Brasil. E-mail: <candidamanfio@gmail.com>.

${ }^{5}$ Universidade Federal de Viçosa, Centro de Ciências Agrárias, Departamento de Fitotecnia, Viçosa, MG - Brasil. E-mail: $<$ motoike@ufv.br>.

${ }^{6}$ Universidade Federal de Viçosa, Centro de Ciências Agrárias, Departamento de Fitotecnia - Viçosa, MG - Brasil. E-mail: $<$ herminia@ufv.br>.

${ }^{*}$ Corresponding author.
}

\begin{abstract}
The macaw palm [Acrocomia aculeata (Jacq.) Lood. ex Mart] has been domesticated to subsidize biodiesel production programs in Brazil. However, little is known about the seedling production of this species. This study aimed to evaluate substrate mixtures, limestone and phosphorus rates for substrate amendment and topdressing frequency in macaw palm seedlings. Three trials were conducted in a greenhouse up to six months of nurserycultivation. Trial 1: determination of percent mineral and organic fractions of seven substrate mixtures. Trial 2: evaluation of four limerates for soil amendment versus four phosphorus rates. Trial 3: evaluation of $\mathrm{N}, \mathrm{K}$ and $\mathrm{Mg}$ topdressing frequency. Significant differences were found in the three trials for most of the variables (plant height, leaf number, shoot dry mass, root dry mass, vigor and bulb diameter). The main results obtained were as follow: Triall - the best seedling growth was observed in substrates with at least $25 \%$ organic matter. Trial 2 -lime rates ranging from 0.50 to $1.25 \mathrm{~kg}$ associated with 3 to $4 \mathrm{~kg}$ of single superphosphate per $\mathrm{m}^{3}$ of substrate providedthe bestseedling growth. Trial 3 - topdressing fertilization provided better development of seedlings regardless of frequency.
\end{abstract}

Keywords: Acrocomia aculeata, fertilization, leaf content.

\section{SUBSTRATOS, CALAGEM, FOSFATAGEM E ADUBAÇÃO DE COBERTURA PARA PRODUÇÃO DE MUDAS DE MACAÚBA}

\begin{abstract}
RESUMO - A macaúba [Acrocomia aculeata (Jacq.) Lood. ex Mart] vem sendo domesticada para subsidiar programas de produção de biodiesel no Brasil. Contudo, pouco se sabe sobre a produção de mudas desta espécie. Objetivou-se avaliar misturas de substratos, doses de calcário e de fósforo na correção do substrato e a frequência de adubação de cobertura em mudas de macaúba. Foram instalados três ensaios conduzidos em casa de vegetação, até o sexto mês de cultivo na fase de viveiro. Ensaio 1: avaliação de percentuais das frações orgânica e mineral totalizando sete misturas de substratos. Ensaio 2: avaliação de quatro doses de correção do solo com calcário versus quatro doses de fosfatagem. Ensaio 3: avaliação da frequência de fertilização com $\mathrm{N}$, Ke Mg em cobertura. Nos três ensaios foram observadas diferenças significativas para maioria das variáveis analisadas (altura de plantas, número de folhas, massa seca da parte aérea, massa seca da raiz, vigor e diametro do bulbo). Como resultados principais têm-se: Ensaio 1 - o melhor desenvolvimento das mudas é observado em substratos com pelo menos $25 \%$ de material orgânico. Ensaio 2 - doses variando de 0,50 a 1,25 kg de calcário associada à fosfatagem com 3,00 a 4,00 kg de superfosfato
\end{abstract}


simples por $m^{3}$ de substrato proporciona melhor desenvolvimento das mudas. Ensaio 3 - a adubação de cobertura proporciona melhor desenvolvimento das mudas independentemente da frequência.

Palavras-chave: Acrocomia aculeata; Fertilização; Teor foliar.

\section{INTRODUCTION}

Macaw palm [Acrocomia aculeata (Jacq.) Lodd. ex Mart] has been exploited for thousands of years by local people where there are natural occurrence of the species. In recent years, because of the high potential for oil production, macaw palms been through an accelerated technological development aiming to develop agricultural production systems to support biodiesel production programs (Pimentel et al., 2011).

The species is, however, still in the process of domestication and has characteristics of wild plants such as high seed dormancy levels and slow initial growth. Motoike et al. (2007) developed a method ofgermination with rates above $80 \%$, enabling the production of pre-germinated seeds of macaw palm. On the other hand, little is known about the seedling production in the species. Therefore, it is necessary to establish seedling production systems, which need to be assessed for the genetic aspects (source material), plant health and nutrition. From a nutritional point of view, it is essential to evaluate substrates, amendment of phosphorus and calcium levels, rates and frequency of topdressing fertilization in order to propose a commercial production system of macaw palm seedlings.

In general, palm tree seedlings are produced from pre-germinated seeds in two consecutive stages: the pre-nursery stage, which extends from pre-germinated seed to the first pair of lanceolate leaves (split leaves) and the nursery stage that extends to the second pair of pinnate leaves (mature leaves). Starting from this point, at which the seedlings are about one year old, field plantingcan begin. The production of palm oil (Elaeis guineensis) seedlings, for example, is based on a substrate made of a mixture of soil (mineral material) with fruit processing waste (organic material) and a monthly topdressing (MÜLLER, 2000).

Among other factors, the production of quality seedlings depends mainly on the substrate and fertilization, which are responsible for the rapid growth and good root system formation. According to Kämpf (2000), the substrate may consist of mineral or organic soil or a mixture of various materials, providing cohesion between the particles to prevent disaggregation at planting, porosity to allow balance between moisture and air, absence of pathogens and weed propagules, and low density. Thus, the choice of material to be used depends on the purpose, availability and cost.

An ideal substrate will provide conditions for the development of the root system, withdesirable chemical, physical and biological characteristics, besides being economically viable forseedling production (WAGNER JÚNIOR et al., 2007). There are many types of substrates, either of mineral or organic origin, or mixtures of these materials, without anyof them being considered suitable for all species (ABAD, 1991).

Therefore, the evaluation of substrates and fertilization systems is a critical step in seedling production of any plant species. Soil, sand or mixtures of these are largely used in the commercial production of seedlings because of the easy availability and low prices. However, substrates containing only mineral materials may have physical and chemical characteristics limiting to the full development of seedlings such as high density and low cation exchange capacity (CEC). In this regard, the production of quality seedlings is attainedby mixing some kind of organic substratewith mineral substrates.

Ribeiro et al. (1999) recommended high doses of lime and fertilizersfor substrate amendment, because of the high value of horticultural products (plants, flowers and vegetable crops). However, forest species have low added value and are largely demanded, which makes it essential to optimize the use of inputs and management to reduce costs and enable the commercial production.

The objective of these experiments was to evaluate the effect of substratemixtures (percentage of organic and mineral fractions), limestone and phosphorus rates for substrate amendment and topdressing frequency on the production of macaw palm seedlings. 


\section{MATERIALAND METHODS}

The study was conducted at the Crop Science Department of the Federal University of Viçosa (UFV). Three trials were carried out in a greenhouse up to six months of nurserycultivation (9-month-oldseedlings, because of the 3-month pre-nursery stage). The seedlings were produced from pre-germinated seeds according to Motoike et al. (2007). The pre-germinated seeds were transplanted to $180 \mathrm{~cm}^{-3}$ tubes containing Plantmax ${ }^{\circledR}$ substrate added with single superphosphate at the rate of $2 \mathrm{~kg} / \mathrm{m}^{3}$ substrate. After three months of pre-nursery (phase in which seedlingsuse mainly the reservesin the endosperm), seedling plantlets with at least one pair of lanceolate leaves were transferred to $4.4-\mathrm{L}$ plastic bags ( $15 \mathrm{~cm}$ diameter $\mathrm{x} 25 \mathrm{~cm}$ height), and the treatments (nursery stage) were applied as described in thesubsections below. The lime and commercial fertilizers used in the experiment included dolomitic limestone (NPR 80\%), single superphosphate, ammonium sulfate, urea, potassium chloride and magnesium sulfate, containing $30 \% \mathrm{CaO}+12 \% \mathrm{MgO}$, $18 \% \mathrm{P}_{2} \mathrm{O}_{5}, 20 \% \mathrm{~N}, 45 \% \mathrm{~N}, 58 \% \mathrm{~K}_{2} \mathrm{O}$ and $10 \% \mathrm{Mg}+$ $13 \% \mathrm{~S}$, respectively.

Acidity correction and fertilization of the substrate used in the three trials was according to recommendations by Ribeiro et al. (1999), oil palm seedling production (MÜLLER, 2000) and results of preliminary trialsprior to the main experiments showing good macaw palm seedling development in substrate with about $1 \mathrm{~kg} / \mathrm{m}^{3} \mathrm{lime}, 4 \mathrm{~kg}$ of single superphosphate and $\mathrm{N}, \mathrm{K}$ and $\mathrm{Mg}$ top dressing at 3-month intervals, i.e., quarterly. This fertilization together with the substrate mixture (soil: sand: farmyard manure in the 2:1:1 proportion)was used as the control treatment (control) in the three trials.

Trials 1 and 2 received three topdressing fertilizations in all treatments, at 60,90 and 150 days after applyingthe treatments. The seedlings received $1 \mathrm{~g}$ of urea, $0.5 \mathrm{~g}$ of potassium chloride and $0.5 \mathrm{~g}$ of magnesium sulfate per application. In Trial 3, the topdressing fertilization were the treatments evaluated.

\section{Trial 1: substrate mixtures}

The experiment was arranged in a completely randomized design (CRD) with seven treatments and four replications. The treatments were as follows: T1 $=\operatorname{soil}($ control $) ; \mathrm{T} 2=\operatorname{soil}+$ sand $(1: 1 \mathrm{v} / \mathrm{v}) ; \mathrm{T} 3=$ soil
+ sand $(2: 1 \mathrm{v} / \mathrm{v}) ; \mathrm{T} 4=$ soil + sand + manure $(1: 1: 1$ $\mathrm{v} / \mathrm{v}) ;=\mathrm{T} 5=$ soil + sand + manure $(2: 1: 1 \mathrm{v} / \mathrm{v}) ; \mathrm{T} 6=$ soil + sand + Plantmax $^{\circledR}(1: 1: 1 \mathrm{v} / \mathrm{v}) ; \mathrm{T} 7=$ soil + sand $+\operatorname{Plantmax}^{\circledR}(2: 1: 1 \mathrm{v} / \mathrm{v})$. Table 1 shows physico-chemical characteristics of the substrates. All substrata received $1 \mathrm{~kg}$ of dolomitic limestone, $4 \mathrm{~kg}$ of single superphosphate, $1 \mathrm{~kg}$ of ammonium sulfate and 0.5 $\mathrm{kg}$ of potassium chloride per $\mathrm{m}^{3}$ substrate.

After the emergence of the first pair of compound leaves (palm trees'characteristic pinnate leaf), around six months in nursery conditions, the following traits of seedlingswere evaluated: shoot length, root length, collar diameter, number of lanceolate leaves (split), number of compound leaves (definitive), vigor (measured by rating scale ranging from 1 to 5 ), shoot dry mass and root dry mass.

Data were examined by analysis of variance and $\mathrm{F}$ test and treatment means were compared by the Tukey's test at $5 \%$ probability level, using the GENES software (CRUZ, 2006).

\section{Trial 2: lime and phosphorus rates in the substrate}

The experiment was arranged in a factorial randomized block design (RBD), with four limestone rates (factor 1) and four phosphorus rates (factor 2), with four repetitions (blocks) and four plants per plot.

The limestone reference level was calculated according to the Neutralizing Exchangeable AluminumMethod and the increase in $\mathrm{Ca}^{2+}$ and $\mathrm{Mg}^{2+}$ levels (RIBEIRO et al., 1999), taking into account aluminum saturation values $(\mathrm{m} \%)$ and total exchangeable bases ( $\mathrm{Ca}$ and $\mathrm{Mg}$ ) found by Motta et al. (2002) in the sites of naturally occurring Macaw Palm in the state of Minas Gerais. Thus, considering only the physical-chemical characteristics of the soil used in substrates (control in Table 1), the lime required (LR in $\mathrm{t} / \mathrm{ha}$ ) was calculated as follows:

$\mathrm{LR}_{\text {(t/ha) }}=\mathrm{Y}\left[\mathrm{Al}^{3+}-(\mathrm{mx} \mathrm{t} / 100)\right]+\left[\mathrm{X}-\left(\mathrm{Ca}^{2+}+\right.\right.$ $\left.\mathrm{Mg}^{2+}\right)$ ]; using $\mathrm{Y}=3 ; \mathrm{m}=20 \% ; \mathrm{X}=3$

Therefore, the LR calculated for the reference soil was $2.46 \mathrm{t} / \mathrm{ha}$. Considering that the limestone used had NPR $=80 \%$, the amount of limestone (AL in $\mathrm{t} /$ ha) to be applied would be approximately three tons, equivalent to $1.5 \mathrm{~kg}$ of lime per $\mathrm{m}^{3} \mathrm{of}$ substrate, which was the maximum rateapplied to the treatments (full liming rate).

Revista Árvore, Viçosa-MG, v.40, n.2, p.235-244, 2016

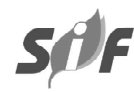


The reference level of phosphorus was according to recommendation by Ribeiro et al. (1999), which is around $1 \mathrm{~kg} \mathrm{P}_{2} \mathrm{O}_{5}$ per $\mathrm{m}^{3}$ of substrate (about $5 \mathrm{~kg}$ of single superphosphate). However, in this trial, the maximum rate applied was $4 \mathrm{~kg}$ of single superphosphate because of the sand mixed in the substrates (low phosphorus retention capacity).

The substrate used in this trial consisted of a mixture of soil, sand and cattle manure (2:1:1, v/v). PH correction was carried out as described above and the soil chemical characterization is described in Table 1 (control). All substrate mixtures were fertilized with $1 \mathrm{~kg}$ of ammonium sulfate and $0.5 \mathrm{~kg}$ of potassium chloride per $\mathrm{m}^{3}$.

After the emergence of the first pair of compound leaves, the seedlings were evaluated for the following phytotechnical characteristics: nutrient contents in the dry matter of leaves and roots, shoot length, root length, stem diameter, number of lanceolate leaves (split), number of compound leaves (definitive), vigor (measured by rating scale ranging from 1 to 5), shoot dry mass and rootdry mass.

Data were examined by analysis of variance and $\mathrm{F}$ test. Variables with significant interaction at $5 \%$ probability level (F-statistic) were subjected to multiple linear regression to obtain a response surface for the interaction lime rate versus phosphorus rate. The software GENES (CRUZ, 2006) was used for the statistical analysis and response surface graphs were generated using StatSoft (2007).

\section{Trial 3: N, K and Mg topdressing frequency}

The experiment was arranged in a completely randomized design (CRD) with four treatments and ten replications. The treatments were as follows: $\mathrm{T} 1$ $=$ without topdressing (control); $\mathrm{T} 2=$ quarterly topdressing (3 and 6 months); T3 = bimonthly topdressing (2, 4 and 6 months); T4 = monthly topdressing (1st, 2nd, 3rd, 4th, 5th and 6th month).

The topdressing fertilization was applied to the treatments individually using a $100 \mathrm{ml}$ solution containing $1 \mathrm{~g}$ of urea, $0.5 \mathrm{~g}$ of potassium chloride and $0.5 \mathrm{~g}$ of magnesium sulfate per seedling in each application.

The substrate for planting seedlings consisted of a mixture of soil, sand and cattle manure $(2: 1: 1, \mathrm{v} /$ $\mathrm{v}$ ), with acidity corrected using $1 \mathrm{~kg}$ of dolomitic limestone per $\mathrm{m}^{3}$ substrate. All substrate mixtures were fertilized with $4 \mathrm{~kg}$ of single superphosphate, $1 \mathrm{~kg}$ of ammonium sulfate and $0.5 \mathrm{~kg}$ of potassium chloride per $\mathrm{m}^{3}$ substrate.

After the emergence of the first pair of definitive leaves, the plants were evaluated for the following phytotechnical features: shoot height, number of leaves lanceolate (split), number of compound leaves (definitive), vigor (measured by rating scale ranging from 1-5), shoot dry mass and root dry mass. Data were examinedby analysis of variance and $F$ test and treatment means were compared by the Tukey's test at $5 \%$ probability level, using the GENES software (CRUZ, 2006).

Tabela 1 - Características químicas de sete misturas de substratos organo-minerais utilizadas para produção de mudas de macaúba.

Table 1 - Chemical characteristics of seven mixtures of organic-mineral substrates used for macaw palm seedling production.

\begin{tabular}{|c|c|c|c|c|c|c|c|c|c|c|c|c|}
\hline \multirow[t]{2}{*}{ Substrate } & \multirow{2}{*}{$\frac{\mathrm{pH}}{\left(\mathrm{H}_{2} \mathrm{O}\right)}$} & $\mathrm{P}$ & $\mathrm{K}$ & $\mathrm{Ca}^{2+}$ & $\mathrm{Mg}^{2+}$ & $\mathrm{Al}^{3+}$ & $\operatorname{CTC}(\mathrm{t})$ & CTC (T) & V & $\mathrm{m}$ & MO & Prem \\
\hline & & \multicolumn{2}{|c|}{$. .\left(\mathrm{mg} / \mathrm{dm}^{3}\right) .}$. & \multicolumn{5}{|c|}{$\ldots \ldots \ldots \ldots \ldots \mathrm{cmol}_{\mathrm{c}} / \mathrm{dm}^{3} \ldots \ldots \ldots \ldots \ldots$} & \multicolumn{3}{|c|}{$\ldots \ldots \% \ldots \ldots$} & $(\mathrm{mg} / \mathrm{L})$ \\
\hline Pure soil* & 5.4 & 4 & 41 & 0.8 & 0.1 & 0.4 & 1.4 & 9.3 & 11 & 28.5 & 2.7 & 9.8 \\
\hline T1 (soil/ctrl) & 5.1 & 153 & 75 & 1.3 & 0.4 & 0.1 & 1.9 & 10.9 & 17 & 5.2 & 2.9 & 19.0 \\
\hline T2 (soil/sand.1:1) & 5.1 & 127 & 44 & 3.8 & 0.3 & 0.0 & 4.2 & 10.1 & 41 & 0.0 & 1.0 & 36.5 \\
\hline T3 (soil/sand.2:1) & 5.1 & 115 & 55 & 4.5 & 0.3 & 0.0 & 4.9 & 12.1 & 41 & 0.0 & 2.0 & 26.0 \\
\hline T4 (soil/sand/man. $1: 1: 1)$ & 5.9 & 246 & 694 & 4.9 & 3.0 & 0.0 & 9.7 & 15.6 & 62 & 0.0 & 5.9 & 39.6 \\
\hline T5 (soil/sand/man. $2: 1: 1)$ & 5.6 & 213 & 493 & 5.4 & 2.4 & 0.0 & 9.0 & 16.5 & 55 & 0.0 & 5.5 & 38.6 \\
\hline T6 (soil/sand/plan. $1: 1: 1)$ & 5.1 & 112 & 169 & 5.3 & 2.2 & 0.0 & 7.9 & 16.3 & 49 & 0.0 & 5.9 & 36.9 \\
\hline T7 (soil/sand/plan.2:1:1) & 5.1 & 112 & 153 & 1.3 & 1.7 & 0.0 & 3.3 & 11.6 & 29 & 0.0 & 5.5 & 27.9 \\
\hline
\end{tabular}

Data:

*Pure soil $=$ soil without fertilizer and correction used in the mixtures of organic-mineral substrate.

CTC - Effective Cation Exchange Capacity (t) and pH 7.0 ( T)

$\mathrm{V}=$ Base Saturation Index

$\mathrm{m}=$ Aluminum Saturation Index

$\mathrm{MO}=$ Organic Matter

$\mathrm{P}$-rem $=$ Remaining Phosphorus

Revista Árvore, Viçosa-MG, v.40, n.2, p.235-244, 2016 


\section{RESULTS}

\section{Trial 1: substrate mixtures}

Seedlings grown in substrates consisted of organicmineral mixtures showed greater height, and greater dry mass of shoots and roots compared with seedlings grown in mineral substrates containing soil and sand (Table 2).

The chemical analysis of substrates (Table 1) showed that all treatments had high fertility levels, comparing with the results of soil analyses suggested by Ribeiro et al. (1999). However, the $\mathrm{K}$ and Mg levels and the percent organic matter were the most important factors contributing to discrepancy between the mineral substrates (T1, T2 and T3) and organic-mineral substrates (T4, T5 T6 and T7), with higher levels in the organicmineral substrates. On the other hand, there was no significant effect of the organic matter proportion in the mixture or the source (Plantmax ${ }^{\circledR}$ or cattle manure), except for root dry mass, in which mixtures of organicmineral substrates with 50\% soil (T5 and T7) showed better results than those with $33 \%$ soil (Table 2 ).

\section{Trial 2: lime and phosphorus rates in the substrate}

There was a low seedling response to substrate correction with $\mathrm{Ca}$ and $\mathrm{P}$, since the shoot dry mass was not affected by the treatments. Only the root dry mass was influenced by the phosphorus rate alone.
This characteristic showed high data variability (coefficient of variation of $45 \%$ ) which made it difficult to fit an accurate mathematical model.

The variables number of lanceolate leaves, number of pinnate leaves, vigor and length of the shoot showed significant interaction between lime and phosphorus rates. In this case, the interaction was investigated by response surfaces, however, no mathematical models were found to fit the data (Figure 1). For number of lanceolate leaves, the interaction lime rate versus phosphorus rate showed the best result (the lowest value, that is, the greatest seedling development) in the $\mathrm{LR}$ range 2.0 to $3.0 \mathrm{t} / \mathrm{ha}$ (Figure 1.1 ).

For number of pinnate leaves, the interaction lime rate versus phosphorus rate showed the best result (highest value) in the LR range 0 to $1.5 \mathrm{t} / \mathrm{ha}$ ( 0 to 0.75 $\mathrm{kg}$ lime $/ \mathrm{m}^{3}$ of substrate) and phosphorus rate ranging from 0 to $1.5 \mathrm{~kg} / \mathrm{m}^{3}$ substrate (Figure 1.2). For the variable vigor, the interaction lime rate versus phosphorus rates howed the best result, that is, the greatestvigor, in the LR range 1.0 to $3.0 \mathrm{t} / \mathrm{ha}\left(0.5\right.$ to $1.5 \mathrm{~kg} \mathrm{lime} / \mathrm{m}^{3}$ of substrate) and phosphorus rate ranging from 2.5 to $4.0 \mathrm{~kg} / \mathrm{m}^{3}$ substrate (Figure 1.3). For shoot length, the interaction lime rate versus phosphorus rate showed the best resulti.e., the highest plant height in the LR range 1.0 to $2.5 \mathrm{t}$ / ha (0.5 to $1.25 \mathrm{~kg}$ of lime / $\mathrm{m}^{3}$ of substrate) and phosphorus rate ranging from 3.0 to $4.0 \mathrm{~kg} / \mathrm{m}^{3}$ substrate (Figure 1.4).

Table 2 - Means of the characteristicsnumber of pinnate leaves (NFP), number of lanceolateleaves (NFL), shoot length (CPA), stem diameter (DCO), shoot dry masss(MSP); root dry mass (MSR) and vigor (VIG) of macaw palm seedlings grown in seven mixtures of organic-mineral substrates.

Tabela 2 - Médias de número de folhas pinadas (NFP), número de folhas lanceoladas (NFL), comprimento da parte aérea (CPA); diâmetro do coleto (DCO), massa de matéria seca da parte aérea (MSP); massa de matéria seca da raiz (MSR) e vigor (VIG) de mudas de macaúba cultivadas em sete misturas de substratos organo-minerais.

\begin{tabular}{|c|c|c|c|c|c|c|c|}
\hline Treatments & $\begin{array}{l}\mathrm{NFP}^{1} \\
\text { (und.) }\end{array}$ & $\begin{array}{l}\mathrm{NFL}^{2} \\
\text { (und.) }\end{array}$ & $\begin{array}{l}\text { CPA } \\
(\mathrm{cm})\end{array}$ & $\begin{array}{l}\mathrm{DCO} \\
(\mathrm{mm})\end{array}$ & $\begin{array}{c}\text { MSP } \\
(\mathrm{g})\end{array}$ & $\begin{array}{c}\text { MSR } \\
(\mathrm{g})\end{array}$ & $\begin{array}{c}\mathrm{VIG}^{3} \\
(1 \text { a } 5)\end{array}$ \\
\hline T1-pure soil/ctrl. & $0,25(1,10) a$ & $4,25(2,28) \mathrm{a}$ & $27,25 \mathrm{c}$ & $9,00 \mathrm{a}$ & $2,50 \mathrm{bc}$ & $2,88 \mathrm{c}$ & $3,75(2,16) \mathrm{a}$ \\
\hline T2-soil/sand 1:1 & $0,00(1,00) \mathrm{a}$ & $4,75(2,38) a$ & $24,37 \mathrm{c}$ & $9,25 \mathrm{a}$ & $1,69 \mathrm{c}$ & $1,94 \mathrm{c}$ & $3,00(1,99) \mathrm{a}$ \\
\hline T3-soil/sand2: 1 & $0,00(1,00) a$ & $5,60(2,55) \mathrm{a}$ & $28,12 \mathrm{c}$ & $10,12 \mathrm{a}$ & $2,47 \mathrm{bc}$ & $3,43 c$ & $3,25(2,04) \mathrm{a}$ \\
\hline T4-soil/sand/man.1:1:1 & $1,00(1,36) \mathrm{a}$ & $5,50(2,55) \mathrm{a}$ & $32,00 \mathrm{bc}$ & $11,00 \mathrm{a}$ & $4,19 \mathrm{ab}$ & $3,56 \mathrm{c}$ & $3,50(2,12) \mathrm{a}$ \\
\hline T5-soil/sand/man.2:1:1 & $1,50(1,57) a$ & $5,00(2,44) \mathrm{a}$ & $45,50 \mathrm{ab}$ & $11,25 \mathrm{a}$ & $4,96 \mathrm{ab}$ & $9,46 a b$ & $5,00(2,45) \mathrm{a}$ \\
\hline T6-soil/sand/plan.1:1:1 & $1,50(1,54) \mathrm{a}$ & $4,75(2,39) \mathrm{a}$ & $36,25 \mathrm{abc}$ & $12,75 \mathrm{a}$ & $3,99 \mathrm{abc}$ & $5,15 \mathrm{bc}$ & $4,25(2,28) a$ \\
\hline T7-soil/sand/plan.2:1:1 & $1,25(1,46) \mathrm{a}$ & $6,00(2,64) \mathrm{a}$ & $49,50^{\mathrm{a}}$ & $13,37 \mathrm{a}$ & $6,04 \mathrm{a}$ & $11,67 \mathrm{a}$ & $5,00(2,45) \mathrm{a}$ \\
\hline Overall Mean & $0,78(1,29)$ & $5,10(2,46)$ & 34,71 & 10,96 & 3,78 & 5,44 & $3,96(2,21)$ \\
\hline $\mathrm{CV}(\%)$ & 20,80 & 7,48 & 18,86 & 25,84 & 33,31 & 38,23 & 9,21 \\
\hline
\end{tabular}

Means in brackets were transformed to follow the normal distribution equation according to the equation: $\mathrm{X}-\sqrt{ }(\mathrm{x}+1)$. Means followed by different letters in the same column differ by the Tukey test at $5 \%$ probability. 


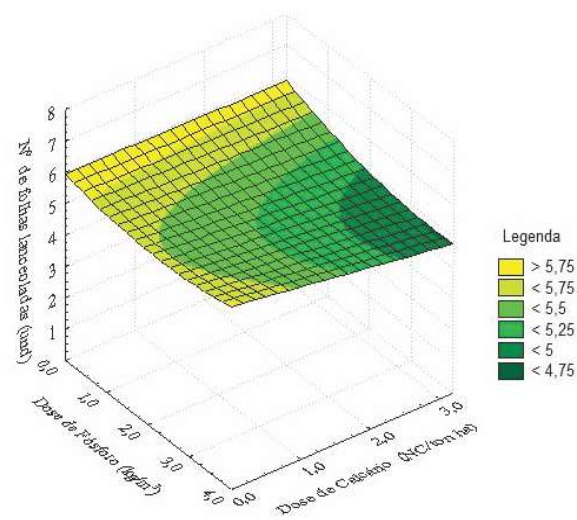

1.1: Number of lanceolate leaves

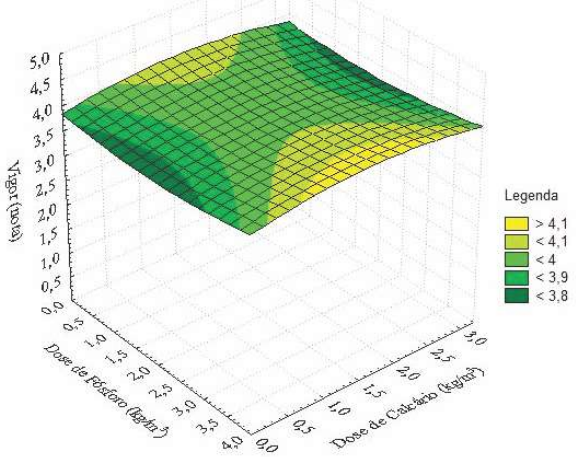

1.3: Vigor ( rating scale from 1 to 5)

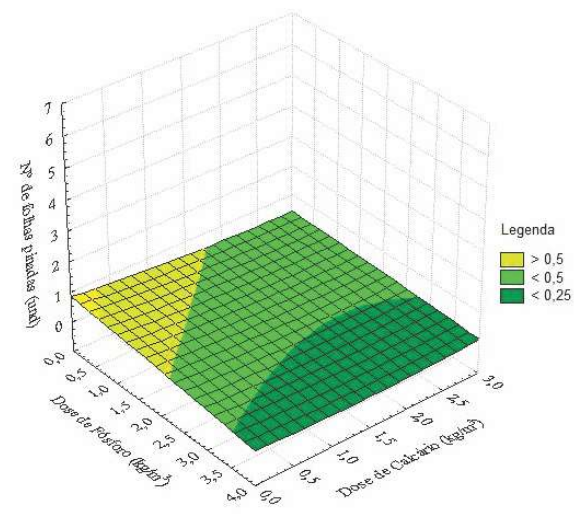

1.2: Number of pinate leaves

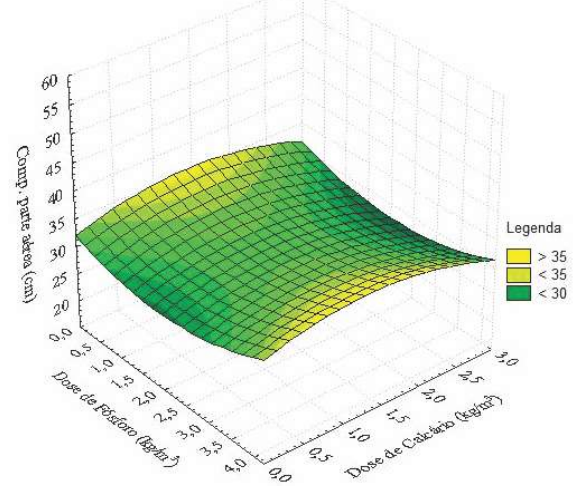

1.4: Shoot length

Data: $\mathrm{X}=$ limeand $\mathrm{Y}=\mathrm{Phosphorus}$

1.1: $\mathrm{Z}=2.62837-0.0049 \mathrm{X}-0.07475 \mathrm{Y}+0.01801 \mathrm{Y}^{2}-0.0151 \mathrm{XY} ; \mathrm{R}^{2}=18.24 \% ;$ sig. $2 \%$

$1.2: Z=1.27765-0.04035 X-0.05845 \mathrm{Y}+0.01148 \mathrm{XY} ; \mathrm{R}^{2}=5.65 \% ; \operatorname{sig} .32 \%$.

$1.3: Z=2.18736+0.06395 \mathrm{X}-0.02 \mathrm{X}^{2}-0.0336 \mathrm{Y}+0.01058 \mathrm{Y}^{2}+0.00188 \mathrm{XY} ; \mathrm{R}^{2}=3.28 \% ; \mathrm{sig} .89 \%$.

$1.4: Z=32.058+4.79264 \mathrm{X}-1.66625 \mathrm{X}^{2}-3.49982 \mathrm{Y}+0.91542 \mathrm{Y}^{2}-0.12566 \mathrm{XY} ; \mathrm{R}^{2}=7.84 \% ; \mathrm{sig} .84 \%$

Figure 1 - Response surface of four characteristics of macaw palm seedlings as a function of different rates of lime and phosphorus in the substrate.

Figura 1 - Superficie de resposta de quatro características avaliadas em mudas de macaúba em função de diferentes doses de calcário e fosforo no substrato.

In addition, the nutrient contents in leaves and roots showed no significant differences between treatments. The means found in the shoot of the seedlings were: Macronutrients in $\mathrm{dag} / \mathrm{kg}, \mathrm{N}=3.23$; $\mathrm{P}=0.22 ; \mathrm{K}=2.04 ; \mathrm{Ca}=1.49 ; \mathrm{Mg}=0.44 ; \mathrm{S}=0.23$, and $\mathrm{Cl}=1.41 ;$ Micronutrients in $\mathrm{mg} / \mathrm{kg}, \mathrm{Fe}=295.63$; $\mathrm{B}=65.84 ; \mathrm{Cu}=3.00 ; \mathrm{ZN}=19.81$ and $\mathrm{Mn}=97.56$. The means found in the roots of the seedlings were: Macronutrients in dag/kg: $\mathrm{N}=1.87 ; \mathrm{P}=0.17 ; \mathrm{K}=2.23$; $\mathrm{Ca}=0.46 ; \mathrm{Mg}=0.65 ; \mathrm{S}=0.28, \mathrm{Cl}=1.45 ;$ Micronutrients, in $\mathrm{mg} / \mathrm{kg}: \mathrm{Fe}=3011.13 ; \mathrm{B}=51.61 ; \mathrm{Cu}=3.00 ; \mathrm{ZN}=$ 22.06 and $\mathrm{Mn}=41.31$.

\section{Trial 3: N, K and Mg topdressing frequency}

There was positive seedling response to all topdressing treatments (T2, T3 and T4) compared with the control ( $\mathrm{T} 1$ - without topdressing) in the nursery stage (Table 3 ). Comparison of the frequency of monthly, bimonthly and quarterly fertilization showed no significant difference for the variables shoot dry mass and plant vigor.

The variables shoot length and number of lanceolate leaves showed the best results with monthly and quarterly 
Table 3 - Means of the characteristics number of pinnate leaves (NFP), number of lanceolate leaves (NFL), shoot length (CPA), shot dry mass (MSP), root dry mass (MSR) and vigor (VIG) of Macaw Palm seedlings grown under different topdressing frequencies.

Tabela 3 - Médias do número de folhas pinadas (NFP), número de folhas lanceoladas (NFL), comprimento da parte aérea (CPA); massa de matéria seca da parte aérea (MSP); massa de matéria seca da raiz (MSR) e vigor (VIG) em mudas de macaúba sob diferentes frequências de adubação de cobertura.

\begin{tabular}{lcccccc}
\hline Treatments & NFP $^{1}$ & NFL $^{2}$ & CPA & MSP & MSR & VIG $^{3}$ \\
\cline { 2 - 6 } & (und.) & (und.) & $(\mathrm{cm})$ & $(\mathrm{g})$ & $(\mathrm{g})$ & $(1 \mathrm{a} \mathrm{5})$ \\
\hline T1 (no top dressing) & $2.00(1.72) \mathrm{a}$ & $3.40(2.09) \mathrm{ab}$ & $46.60 \mathrm{c}$ & $14.56 \mathrm{~b}$ & $16.70 \mathrm{a}$ & $4.20(2.28) \mathrm{b}$ \\
T2 (quarterly topdressing) & $2.10(1.75) \mathrm{a}$ & $3.30(2.07) \mathrm{ab}$ & $60.30 \mathrm{ab}$ & $17.99 \mathrm{ab}$ & $19.03 \mathrm{a}$ & $4.50(2.34) \mathrm{ab}$ \\
T3 (bimonthly topdressing) & $1.80(1.66) \mathrm{a}$ & $4.00(2.23) \mathrm{a}$ & $53.50 \mathrm{bc}$ & $17.87 \mathrm{ab}$ & $18.67 \mathrm{a}$ & $4.60(2.37) \mathrm{ab}$ \\
Overall Mean & $2.20(1.78) \mathrm{a}$ & $2.60(1.88) \mathrm{b}$ & $66.90 \mathrm{a}$ & $21.47 \mathrm{a}$ & $23.40 \mathrm{a}$ & $4.90(2.43) \mathrm{a}$ \\
Ov & $2.02(1.72)$ & $3.32(2.07)$ & 56.82 & 17.97 & 19.45 & $4.55(2.35)$ \\
CV(\%) & 11.38 & 10.22 & 13.53 & 27.74 & 33.93 & 5.17 \\
\hline
\end{tabular}

1,2 and 3

Means in brackets were transformed to follow the normal distribution equation according to the equation: $\mathrm{X}-\sqrt{ }(\mathrm{x}+1)$. Means followed by different letters in the same column differ by the Tukey test at $5 \%$ probability.

fertilizations, followed by bimonthly fertilization and without topdressing, in that order (Figure 2).

\section{DISCUSSION}

\section{Trial 1: substrate mixtures}

Seedlings grown in the substrates of organic-mineral mixtures showed the best results. This effect is due to the physical structure of the substrate with formation of soil aggregates, which improves the balance between macro and micropores and, therefore, water retention.
Hartmann et al. (1990) attributed the beneficial effect of mixtures with organic materials in the production of seedlings to the improvement of texture, which favors the root development. The chemical analysis of substrates (Table 1) showed that all treatments had high fertility levels, comparing with the results of soil analyses suggested by Ribeiro et al. (1999). However, the factors with the greatest discrepancy between the mineral substrates (T1, T2 and T3) and organic-mineral substrates (T4, T5 T6 and T7) were $\mathrm{K}, \mathrm{Mg}$ and proportion of organic matter, which showed the highest values in organic-

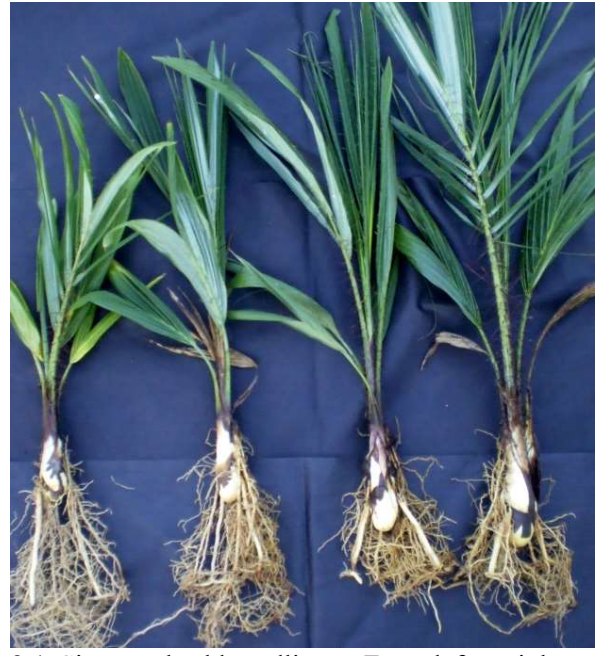

2.1 Six-month-old seedlings. From left to right : T1; T2; T3 eandT4.

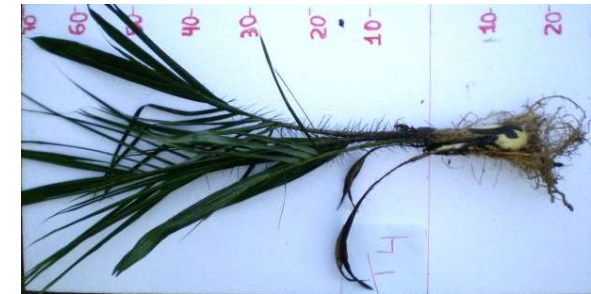

2.2 Fully developed seedlings at 6 months of age

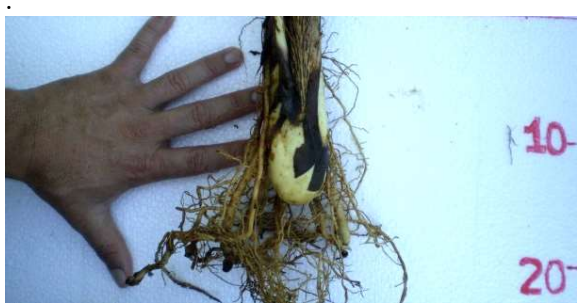

2.3 Fully developed bulb and roots of six-monthold seedlings

Figure 2 - Development of macaw palm seedlings grown under different topdressing frequencies.

Figura 2 - Desenvolvimento de mudas de macaúba em função da frequência de adubação de cobertura. 
mineral substrates. Motta et al. (2002) found high levels of organic matter and potassium in soils with naturally occurring macaw palm, characterizing agreat demand of the species for these two nutrients.

Similar results were reported by other authors. Martins Filho et al. (2007), studying substrate mixtures for palm tree in commercial nurseries, reporte different responses of palm trees pecies to the type of organic compost. However, the mixture of soil, sand and manure was superior to the others for the two species studied, indicating that cattle manure is an organic source suitable for the production of palm seedlings.

Fruit trees, in general, follow the same trend. Wagner Junior et al. (2007) studied substrates for production of fruit seedlings and found the best results for mixtures of soil with commercial substrates, showing that the mixture of mineral and organic materials are suitable for plant propagation.

In this study, however,we found no significant effect for both the proportionof organic matter in the mixture and the source (Plantmax ${ }^{\circledR}$ or cattle manure) (Table 2), except for root dry mass, in which mixtures of organic-mineral substrates with $50 \%$ soil gave better results than those with $33 \%$ soil. These treatments probably had a better substrate structuring because of the greater soil proportion, improving the substrate physical characteristics and favoring root development.

Thus, the results indicate that $25 \%$ of organic substrate is sufficient to produce macaw palm seedlings with good quality. However, despite cattle manure being an easily availableand low-cost material, it has the disadvantage of carrying weed seeds, causing problems in commercial nurseries. Nevertheless, this study evaluated only phytotechnical characteristics of seedlings related to quality and development.

\section{Trial 2: lime and phosphorus rates in the substrate}

The low initial response of the seedlings to substrate acidity correction may be due to the slow initial seedling development and the use of seed reserves, since the seed remains ad hered to the plant providing nutrients until around the fourth month. Subsequently, there is a higher seedling development rate and therefore an increased demand for external nutrients (from the substrate). In this study, only the root drymass was influenced by the phosphorus rate. Marschner (1995) discussed that plants with low phosphorus supply tend to have higher root/shoot ratio than plants with adequate supply. This effect was observed in this experiment, because the plants with low phosphorus supply had higher root dry mass, indicating that there was a change in the assimilate partition and plants had to compensate for the lack of nutrients in the substrate with more roots. Therefore, despite not having detected significant differences in the shoots up to the sixth month of age, it is likely that in subsequent stages of development, there could be differentiated growth in response to $\mathrm{P}$ and $\mathrm{Ca}$ rates, since up to this stage, the plant had already signaled differentiated growth due to available $P$.

There was a significant interaction between the limestone and phosphorus rates for the variables number of pinnate leaves, number of lanceolate leaves, shoot length and vigor, however, the tested mathematical models showed poor fit and the visual effects were little expressive. Teixeira and Macedo (2011) studied the effect of lime and phosphate on the production of Rollinia mucosa seedlings and also found low response to substrate correction. It is probably that tropical forest species, which have evolved in acid soils and low $\mathrm{Ca}$ and $\mathrm{P}$, have a small initial response to substrate correction.

In general, the best responses were observed for intermediate rates of lime and high rates of phosphorus. According to Novais et al. (2007), the adsorption of phosphorus by iron and aluminum oxyhydroxidesis directly linked to the soil $\mathrm{pH}$. When the soil $\mathrm{pH}$ is corrected with lime, it is expected a lower $\mathrm{P}$ adsorption and consequently a greater availability of this nutrient to the plant. On the other hand, high doses of limestone can have an antagonistic effect, since the phosphoruswill bind calcium, forming calcium phosphate, which has a low solubility and will precipitate in the soil solution. Thus, the balance between phosphorus levels and limestone is important to maximize production and optimize the use of these inputs.

Despite the wide response range to the treatments (Figure 1), it can be inferred that the best seedling growth occurs when the substrate is corrected to LR varying from 1.0 to 2.5 ton of limestone per ha $(0.50$ to $1.25 \mathrm{~kg}$ lime $/ \mathrm{m}^{3}$ of substrate) combined with a phosphorus rate of 3.0 to $4.0 \mathrm{~kg}$ of single superphosphate per $\mathrm{m}^{3}$ of substrate. This range of substrate correction provided the best seedling growth indicators for most of the evaluated characteristics. 


\section{Trial 3: N, K and Mg topdressing frequency}

There was positive response of seedlings to all topdressing treatments compared with the control. No significant difference was detected for shoot dry mass and plant vigor in response to frequency of fertilization, indicating that the quarterly fertilization would be sufficient to produce quality macaw palm seedlings (Figure 2).

Shoot length and number of lanceolate leaves had the best results with monthly and quarterly fertilizations. It is important to note that the number of lanceolate leaves (split leaves) is a characteristic correlated negatively with seedling development. The greater the number of split leaves, the earlier the developmentals tage of the seedling. On the other hand, a larger number of pinnate leaves (definitive) would be related to the most advanced seedling developmentals tage. Thus, the treatments 1, 2 and 3 showed the greatest number of split leaves indicating a lesser degree of seedling development compared with treatment 4 (monthly topdressing).

It is important to consider that the production of macaw palm seedlings has been carried out according to procedures based on the commercial seedling production of palm oil (Elaeis guineensis). The fertilization of palm oil starts 30 days after seedling transplanting, using NPK $+\mathrm{Mg}$ solutions (MÜLLER, 2000). At 60 days, still at the pre-nursery stage, fortnightly top dressing sare carried out to provide about $0.1 \mathrm{~g}$ of urea, 0.1 $\mathrm{g}$ of triple superphosphate, $0.02 \mathrm{~g}$ of potassium chloride and $0.02 \mathrm{~g}$ magnesium sulfate per seedling. In the nursery stage, monthly fertilizations are carried out with 10 g of $\mathrm{NPK}+\mathrm{Mg}$, in the ratio 12:17:10+3, per seedling. However, some differences between the production system of seedlings of Macaw Palm and palm oil must be considered. In the case of palm oil, the seedlings are propagated in bags (approx. $20 \mathrm{~L}$ ), containing basically soil (O horizon, with high organic matter content), whereas macaw palm seedlings are produced in smaller bags, about $5 \mathrm{~L}$, because of the greater hardiness and tolerance to water deficit. Thus, fertilization requirements may also be reduced and also the demand for inputs and management in the nurseries, resulting in a more economical seedling production system. This hypothesis was confirmed in this experiment, since the quarterly topdressing was sufficient to produce good quality seedlings. However, monthly topdressed seedlings showed greater precocity.

\section{CONCLUSIONS}

\section{Trial 1: relating to substrates}

- Organic-mineral substrates (soil + sand + manure or Plantmax ${ }^{\circledR}$ ) provided better seedling development than mineral substrates (pure soil or soil + sand);

- The ratio of $25 \%$ organic material in the substrate composition is suitable for producing good quality macaw palm seedlings.

\section{Trial 2: relating to substrate acidity correction}

- The substrate acidity correction had little effect on the initial development of macaw malm seedlings;

- The best seedling development occurred in the lime requirement rangebetween 1.0 and $2.5 \mathrm{t} / \mathrm{ha}(0.50$ to $1.25 \mathrm{~kg}$ of limestone per $\mathrm{m}^{3}$ of substrate) and phosphorus rate between 3.0 and $4.0 \mathrm{~kg}$ of single superphosphate per $\mathrm{m}^{3}$ substrate;

\section{Trial 3: relating to topdressing fertilization}

- Macaw palm seedlings respond to $\mathrm{N}, \mathrm{K}$ and $\mathrm{Mg}$ topdressing in the nursery;

Topdressing, regardless of frequency, provides greater height, greater shoot dry mass and seedling vigor;

- Quarterly topdressingof $1 \mathrm{~g}$ urea, $0.5 \mathrm{~g}$ potassium chloride and $0.5 \mathrm{~g}$ magnesium sulfate per seedling was sufficient to produce good quality macaw palm seedlings;

- Monthly topdressingof $1 \mathrm{~g}$ urea, $0.5 \mathrm{~g} \mathrm{KCl}$ and $0.5 \mathrm{~g}$ magnesium sulfate per seedling provided greater precocity of production in the nursery.

\section{ACKNOWLEDGEMENTS}

The authors thank CNPq (for granting the scholarship), FINEP and EMBRAPA for funding the research project (Propalma project) and the Federal University of Viçosa for providing the facilities to carry out this study.

\section{REFERENCES}

ABAD, M. Los sustratos hortícolas y técnicas de cultivo sinsuelo. In: RALLO, L.; NUEZ, F. La horticultura Españolaenla C.E. Réus: Horticultura S.L., 1991. p.271-280.

Revista Árvore, Viçosa-MG, v.40, n.2, p.235-244, 2016 
CRUZ, C.D. Programa Genes: Biometria. Viçosa, MG: UFV, 2006. 382p.

HARTMANN, H.T.; KESTER, D.E.; DAVIES JUNIOR, F.T. Plant propagation: principles and practices. 5.ed. EnglewoodCliffs: Prentice Hall, 1990. 642p.

KÄMPF, A.N. Seleção de materiais para uso como substratos. In: KÄMPF, A.N.; FERMINO, M.H. (Ed.). Substratos para plantas: a base da produção vegetal em recipientes. Porto Alegre: Gênesis, 2000. p.139-145.

MARSCHNER, H. Mineral nutrition of higher plants. $2^{\text {nd.ed. }}$ London: Academic Press, 1995. 889p.

MARTINS FILHO, S.; ADÉSIO, F.; ANDRADE, B.S.; RAGEL, R.M.; SILVA, M.F. Diferentes substratos afetando o desenvolvimento de Mudas de palmeiras. Revista Ceres, v.54, n.3011, p.80-86, 2007.

MOTOIKE, S.Y.; LOPES, F.A.; SÁ JUNIOR, A.Q.; CARVALHO, M.; OLIVEIRA, M.A.R. Processo de germinação e produção de sementes prégerminadas de palmeiras do gênero Acrocomia.

Patente: PI0703180-7. 2007.

MOTTA, P.E.; CURI, N.; OLIVEIRA FILHO, A.T.; GOMES, J.B.V. Ocorrência de macaúba em Minas Gerais: relação com atributos climáticos, pedológicos e vegetacionais. Pesquisa. Agropecuária Brasileira, v.37, p.10231031, 2002.

MÜLLER, A.A. Produção de mudas de dendezeiro.
In: VIÉGAS, I.J.M.; MÜLLER, A.A. (Ed.). A cultura do dendezeiro na Amazônia Brasileira. Belém: Embrapa Amazônia Oriental/ Manaus: Embrapa Amazônia Ocidental, 2000. p.175-191,

NOVAIS, R.F.; SMYTH, T.J.; NUNES, F.N. Fósforo. In: NOVAIS, R.F.; ALVAREZ V., V.H.; BARROS, N.F.; FONTES,R.L.F; CANTARUTTI, R.B.; NEVES, J.C.L. (Ed.). Fertilidade do solo. Viçosa, MG: SBCS, 2007. p.471-550.

PIMENTEL, L.D.; MANFIO, C.E.; MOTOIKE, S.Y.; PAES, J.M.V; BRUCKNER, C.H. Coeficientes técnicos e custos de produção do cultivo da macaúba. Informe Agropecuário, v.32, n.265, p.61-69, 2011.

RIBEIRO, A.C.; GUIMARÃES, P.T.G.; ÁLVAREZ V., V.H. (Ed.). Recomendações para uso de corretivos e fertilizantes em Minas Gerais $-5^{\text {a }}$ aproximação.Viçosa, $\mathrm{MG}$ : CFSEMG, 1999. 359p.

STATSOFT, Inc. STATISTICA (data analysis software system), version 8.0. 2007. www.statsoft.com.

TEIXEIRA, P.C.; MACEDO, S.T. Calagem e fósforo para a formação de mudas de biribazeiro. Revista de Ciências Agrárias., v.54, n.3, p.259-266, 2011.

WAGNER JÚNIOR, A.; SILVA, J.O.C.; SANTOS, C.E.M.; PIMENTEL, L.D.; NEGREIROS, J.R.S.; ALEXANDRE, R.S.; BRUCKNER, C.H. Substratos na formação de mudas para pessegueiro.

Revista Acta Scientiarum, v.29, n.4, p.569$572,2007$. 